\title{
A Learning Style Comparison between Synchronous Online and Face-to-Face Engineering Graphics Instruction
}

\author{
Wade H. Goodridge ${ }^{1}$, Oenardi Lawanto ${ }^{1} \&$ Harry B. Santoso ${ }^{2}$ \\ ${ }^{1}$ Department of Engineering Education, Utah State University, Logan, Utah \\ ${ }^{2}$ Faculty of Computer Science, Universitas Indonesia, Jawa Barat, Indonesia \\ Correspondence: Wade H. Goodridge, Department of Engineering Education, Utah State University, Logan, UT., \\ 84321, United States. Tel: 1-435-797-9051. E-mail: wade.goodridge@usu.edu; Harry B. Santoso, Faculty of \\ Computer Science, Universitas Indonesia, Jawa Barat, Indonesia. E-mail: harrybs@cs.ui.ac.id
}

Received: April 6, 2016

doi:10.5539/ies.v10n2p1

\author{
Accepted: May 16, 2016 \\ Online Published: January 30, 2017 \\ URL: http://dx.doi.org/10.5539/ies.v10n2p1
}

\begin{abstract}
The implementation of a successful engineering program to a synchronous online curriculum is subject to many impacting factors. One such factor, that has not seen much investigation, concerns learning styles. Student learning styles may have a dramatic influence on the success of a synchronous online deliverable engineering graphics curriculum. The immediate objective of this research was to look at the effectiveness of teaching Engineering Graphics with a synchronous online delivery method and to compare it to a more traditional face-to-face delivery method. Using Kolb's learning style inventory, student learning styles in both educational settings were investigated and analyzed to discover the student population's prevailing learning style. Data relating to class success was collected with surveys, personal feedback, and by observing overall student performance based on grades and responses to the survey material presented. The study targeted 6 separate sections of an engineering graphics course taught by the same instructor, in the same physical setting, and with identical curricula over a two-year period. Data analysis allowed for an introspective look into correlations between academic success and the learning styles of the students. Findings suggest that (1) Converger students receive significantly higher final course grades when they are in a synchronous online environment; (2) Assimilator and Converger synchronous online students show significant improved differences in their final open-ended project scores over their face-to-face taught peers, the prevalent learning style within the course. Suggestions to accommodate learning styles are present.
\end{abstract}

Keywords: distance education, engineering graphics, face-to-face instruction, Kolb's learning style inventory, synchronous online instruction

\section{Introduction}

The delivery of course curriculum to students at remote locations through synchronous or asynchronous methods is often termed distance education. With better technology and delivery methods distance education has taken a prominent foothold in the academic community. There are some stereotypes that still stigmatize this form of education. Many individuals still associate the distance education model as one strictly involving a one-way lecture medium. This older model, that involved video media and correspondence materials, has now been replaced and enhanced by upgraded networking technology, better research, and a higher demand for educational opportunities by students. With this gain in interest and improved delivery mechanisms, distance education is beginning to establish itself within the engineering disciplines. The learning styles present in engineering students may be of impact upon their potential success within these rigorous majors.

Allen and Seaman report that over 6.1 million students are currently enrolled in at least one online course in the fall of 2010 (Allen \& Seaman, 2011). Similar reports by the same authors shows the history of such enrollments in online education with numbers at more than 5.6 million for the fall of 2009 (Allen \& Seaman, 2010), more than 4.6 million for the fall of 2008 (Allen \& Seaman, 2008), and more than 3.94 million for the fall of 2005 (Allen \& Seaman, 2005). These surveys sampled more than 2,500 colleges and universities nationally. The figures represent the recent increase in interest and enrollments for online programs throughout our nation by individuals seeking to further education in alternative forms. 
Previous research has investigated learning styles of students in some fields such as Accounting (Warn, 2009), Agriculture (Cano \& Garton, 1994), Chemistry (Yeung, Read, \& Schimd, 2005), Social Sciences (Abidin, Rezaee, Abdullah \& Singh, 2011), and Web-based asynchronous course delivery (Hsieh \& Dwyer, 2009). However, there is still limited studies and knowledge base regarding learning styles impacts and their impacts in synchronous online and face-to-face classrooms. This is especially true in engineering courses such as the engineering graphics course this study is situated to investigate. With an understanding of learning styles impacts upon academic performance in synchronous online and face-to-face delivered courses, better instructional approaches can be developed.

\section{Relevant Literature Review}

\subsection{Online Engineering Education}

There has been an acknowledged resistance for the development of online engineering curriculums discussed in the literature. Bourne, Harris, and Mayadas (2005) point out the slow embracement of online engineering programs while Ibrahim and Morsi (2005) point out academic arguments concerning required engineering laboratory experiences and their difficulty in implementation. Online laboratory experiences should be equitable to experiences gained in traditional laboratories delivered with traditional methods (Bourne, Harris, \& Mayadas, 2005; Grose, 2003; Ibrahim \& Morsi, 2005; Peterson \& Feisel, 2002). Progressive work regarding lab experiences is currently being developed. Literature is now reflecting an emphasis in the development of virtual and remote laboratory experiences for online engineering students (Chen, Song, \& Zhang, 2010; Chen, Olmi, \& Song, 2010; Cooper, 2005; Hesselink et al., 2003; Saad, Saliah-Hassane, Hassan, El-Guetioui, \& Cheriet, 2002) leading the way into finding legitimate laboratory alternatives. An additional barrier with some engineering education faculty is a sense that online education is typified by an isolated, individualized, self-paced instruction model (Bourne, Harris, \& Mayadas, 2005). In no way should this be or is it always the norm.

Research exists regarding the creation of quality online engineering education programs (Bourne, Harris, \& Mayadas, 2005; Subic \& Maconachie, 2004). Work has been conducted involving team teaching (Minichiello, Goodridge, Blake, \& Sam, 2011), the recognition of pre-entry variables (Dupin-Bryant, 2004), motivation and retention (Huett, Kalinowski, Moller, \& Huett, 2008), interaction and social presence (Picciano, 2002; Swan, 2001), learning effectiveness (Swan, 2003), predicting student success (Simpson, 2006), and self-efficacy and cognitive styles (DeTure, 2004). Work regarding learning styles has also been conducted concerning online course design (Koehler, Mishra, Herhey, \& Peruski, 2004), predominant learning styles and gender impacts on course design (Eom, Wen, \& Ashill, 2006; Garland \& Martin, 2005) and online course success (Terrell \& Dringus, 2000). The later work highlights the possible results of learning styles and their impacts on dropout rates for online classes.

\subsection{Individual Differences in Learning: Learning Style and Performance}

Literature indicates many important insights regarding individual differences in learning. Inherent in these differences is the learning style that the student naturally utilizes during their acquisition of content. Of large consequence is the acknowledgment that students differ greatly in how they learn (Bargar, Bargar, \& Cano, 1994; Dunn \& Dunn, 1979) and that learners with different learning styles will behave differently in the way they perceive, interact, and respond to the learning environment (Junko, 1998). Additionally, there has been an increase in diversity of learning styles at higher educational institutions (Schroeder, 1993). The recent increase towards online education instruction will increase this diversity even further. Anderson and Adams (1992) point to a need to be aware of different learning styles. Understanding a learner's preference for information acquisition can help teachers become more sensitive to the differences students bring into the classroom (Felder \& Spurlin, 2005) and let us target multiple learning styles with our delivery methods increasing the effectiveness of our instruction.

Learning style and academic performance are highly correlated within the literature. Cano and Garton (1994) and subsequent independent work by Cano (1999) and Garton et al. (1999) point out how a student's specific learning style influences their academic achievement. There have also been noted correlations in how a learner learns (learning style was used as a measurement) and how much a learner learns (cumulative GPA was used as a measurement) (Torres, 1993; Torres \& Cano, 1993). Garcia and Hughes (2010) point out the relationship between learning styles and teaching/learning constructs and mention the importance of adapting one's own style to assessment and teaching styles as a requisite to academic achievement. However, with reflection of all this work, there is not enough significant research showing learning style correlation to academic achievement within a synchronous delivered online engineering graphics course. 


\subsection{KOLB Learning Styles Inventory}

The Kolb's learning style inventory (LSI) provides a valid model to measure and assess student learning styles (Kolb, 1984; Kolb \& Kolb, 2005a; 2005b). David Kolb's LSI is based on an Experiential Learning Model (Kolb, 1984). Compared to other learning styles such as Myers-Briggs Type Indicator (Myers, 1990, 1995; Myers, McCaulley, Quenk, \& Hammer, 1998), Felder-Silverman learning style model (Felder \& Silverman, 1988; Felder \& Spurlin, 2005; Litzinger, Lee, Wise, \& Felder, 2007), and VARK (Leite, Svinicki, \& Shi, 2010), Kolb's LSI introduces a holistic framework of teaching and learning.

It has been demonstrated that Converger learning styles outlined by Kolb are associated with student performance (Lynch et al., 1998) and that Converger students tend to perform better on conventional exams involving concrete answers. The Converger learning style is often an area that many engineering professionals and students classify within (Kolb, 1984; Kolb \& Kolb, 2005a). This correlation as well as Kolb's LSI popularity within the distance learning research community (Diaz \& Cartnal, 1999) leads to the author's choice to use this LSI within this study.

According to Kolb, students apply four types of dialectic learning modes or orientations: concrete experiences (CE) and abstract conceptualization (AC), as well as reflective observation (RO) and active experimentation (AE) (Kolb, 1985). The concrete experience learning mode emphasizes "...concern with the uniqueness and complexity of present reality as opposed to theories and generalizations" (Kolb, 1984, p. 68). Reflective observation emphasizes visual experience prior to making any judgments. Abstract conceptualization involves the analysis of any ideas while active experimentation "focuses on actively influencing people and changing situations" (Kolb, 1984, p. 69).

The Kolb's LSI categorizes learners' learning styles as accommodating, diverging, assimilating, or converging. Each learning style is a resultant of two learning modes. Typical preferences for each learning style are now elaborated on. Accommodating (CE/AE) learners prefer to combine concrete experience and active experimentation and are students that can be qualified by the terms "feel" and "do". They are hands on learners that will rely on intuitive decisions more than logical ones and prefer a more lab-like practical and experiential approach to their problem solving process. This learning style is common to those roles requiring action and initiative (Dahbi, Elkamoun, \& Berraissoul, 2006). Diverging (CE/RO) learners prefer to combine concrete experience and reflective observation and are those who prefer to "watch" and "feel". They often are able to look at things from different perspectives and gather information to derive imaginative solutions to problems. This type of individual excels at brainstorming, tends to be interested in people, and is usually strong in the arts (Dahbi, Elkamoun, \& Berraissoul, 2006). Assimilating (AC/RO) learners prefer to combine abstract conceptualization and reflective observation and fall within the "think" and "watch" category. Their preference within a problem solving approach is towards being concise and logical. They like clear and succinct explanations and excel at organizing wide ranges of information into a clear logical format. This learning style reflects an individual who is more focused on ideas and abstract concepts than on other individuals. Students falling in this category prefer readings, formal lectures and analytical models (Dahbi, Elkamoun, \& Berraissoul, 2006). Converging (AC/AE) learners prefer to combine abstract conceptualization and active experimentation and can be considered thinkers and doers. This type of learner will direct their learning to the solutions of very practical problems. They prefer technical tasks and are adept at applying and finding uses for theories and ideas. These individuals are less concerned with the interpersonal aspects of group and team solutions and are attracted more to the technical tasks involved (Dahbi, Elkamoun, \& Berraissoul, 2006).

Possible correlations between learning style and academic performance within a synchronous online engineering graphics course can lead to improvements in curriculum and pedagogy that will allow instructors to enhance their course as well as accommodate non-dominant learning styles and thus improve student retention (Terrell \& Dringus, 2000). With acknowledgment that most engineering degrees require some type of computer aided engineering graphics course, the results discovered within such a study has broad impacts spanning secondary, college, and university levels.

\section{The Study}

\subsection{Context of the Study}

With a recent adoption of some online engineering courses a western American University presented an opportunity to allow the investigation of learning styles impact upon student academic performance in an introductory engineering graphics solid modeling course. The particular course studied is a pre-engineering program requirement for students (occurring in the first two years before students enter professional courses at the junior and senior level) pursuing a mechanical engineering degree and is typically taken in their freshman 
year.

Four sections of this course were synchronously delivered via broadcasting software allowing audio and desktop video capture to be broadcast to the student's computer. The software, called Wimba ${ }^{\mathrm{TM}}$, allowed the instructor to directly display the software interface to the students. In addition, the software allowed student instructor interface through typed questions and various responses marked within the dialogue portion of the broadcast software's interface. PowerPointTM lessons regarding software use and graphics theory was delivered through the same medium to the students. Demonstrations on the software the course teaches was captured and broadcast from the instructor's computer to the student's computers and an overhead screen for the synchronous online courses. Two sections of the course were also sampled that delivered face-to-face instruction using a traditional lecture format. Lectures used the same PowerPoint slides and same solid modeling software projected to an overhead screen and student's computers.

All sections were taught by the same instructor with the same teaching assistants present. All sections used identical curriculum and assessments. All six studied sections where taught in the same room in the Engineering building with the only distinct difference involving the physical presence of the instructor for the synchronous online courses. Recognizing that it is usually inferred that online students are taking a class isolated and separate from their peers, it is important to point out that this class had all students from both studied groups in the same location. Synchronous online students were therefore in the same physical environment as their face-to-face peers. The course teaching assistants where identical for all sections studied and students could address questions to them or the instructor throughout the lectures. Questions posed to the instructor from the synchronous online course were typed into the Wimba ${ }^{\mathrm{TM}}$ software by the students and where visible and addressed immediately by the instructor during the lecture. Face-to-face student's questions were answered in the traditional manner. Opportunities for peer-to-peer interaction during lecture and during course activities were identical between the studied groups.

By comparing the synchronous online and face-to-face classes, the research question guiding this study is "Is there any difference on academic performance (final grades and open-ended problem scores) across learning styles between synchronous online and face-to-face classes?"

\subsection{Participants}

This quasi-experimental, pre-post intervention study involved 6 course sections of the MAE 1200 Engineering Graphics with a total student sample of 108 students (i.e., 30 synchronous online and 78 face-to-face students). The study utilized a convenience sample with an intervention focused on the method of instruction: face-to-face versus synchronous online instruction. The study was taught by the same instructor with identical curriculum over a two-year period. All six sections of the course studied where present in the same computer lab throughout the study. Four of the investigated course sections utilized a synchronous online delivery approach while two sections involved the traditional face-to-face delivery method prevalent across most universities. The course teaching assistants where identical for all sections studied and both were present in the class during the study. Teaching assistants where encouraged to help students in both face-to-face and synchronous online course sections.

\subsection{Course Performance Evaluation}

Course performance was evaluated with a composite final course grade developed from 13 solid modeling homework assignments focused on student knowledge of software commands, seven solid modeling quizzes with the same focus, two assembly projects using the software and requiring interpretation of provided documents, a midterm, a final, and the capstone activity. The homework and quizzes weighted at $15 \%$ of the total grade, the midterm and final at $20 \%$ each, the two assembly projects at $5 \%$, and the capstone activity at $25 \%$.

\subsection{Open-Ended Problems}

This college engineering graphics course delivered a curriculum that emphasized an open ended, ill structured final design project as a capstone activity. Students begin the semester learning how to use the Solid Edge ${ }^{\mathrm{TM}}$ solid modeling software and then begin to engage in the design project close to two-thirds of the way through the semester. The design project focused on the creation of a robotic arm in solid modeling software capable of picking up and transporting a ping pong ball and a pencil. Students are allotted 4 weeks to complete their designs including part generation, assembly, and animation.

The main focus of the activity was directed towards the development of a robotic gripper and the arm components of the robotic arm. The design of the former required it to be versatile enough to handle the two objects without changing the gripper mechanism. Students were initially presented with a theoretical setting for 
the robot in an assembly line manufacturing process. This robot would move the items from one belt to another. Students work in teams of two to solve the problem dividing up the invented arm and gripper components between them. Students were encouraged to think economically about cost and applicable materials. The work envelope provided for the robotic arm was also set to given dimensions simulating constraints that often exist in engineering. Students were encouraged to verify part interaction on completed assembly models throughout their design process. This ensured final prototype validity.

Solutions were analyzed by their adherence to the engineering constraints of size and economy and a successful robotic arm was required to be demonstrated via animation in the Solid Edge ${ }^{\mathrm{TM}}$ software. Appropriate avi movie files of the robotic arm operating was part of the documentation required was also a component in the final solutions grade. Dimensioned multi-view drawings, an isometric drawing, and jpeg picture files as well as required design journal entrees where collected and graded showing the evolution of the design process. Outcomes for curricular materials can be seen in Figure 1.

\subsection{Instrumentation}

In this study, Kolb's (2005) Learning Style Inventory 3.1 was used to collect data on students' dominant learning styles. According to studies conducted by Kayes (2005) and Wierstra and DeJong (2002), the corresponding alpha reliability scores reported on this instrument for concrete experience (CE), reflective observation (RO), abstract conceptualization (AC), and active experimentation (AE) were $.81, .78,83$, and .84 , respectively. The questionnaire is designed to capture the main features of the Kolb's Learning Style Inventory (i.e., learning modes): concrete experience (CE), reflective observation (RO), abstract conceptualization (AC), and active experimentation (AE).

The Kolb' Learning Style Inventory consists of 12 questions. Each question has 4 answers and each answer represents one learning mode. Students need to rate all answers based on their preferences and measurement scales of each answer ranged from ranks of 1 to 4 (i.e., rank 1 indicates the least appropriate fit and rank 4 indicates the best fit). Table 1 shows the example of Kolb's Learning Style Inventory.

\begin{tabular}{|c|c|}
\hline Outcome of Open Ended Project & Outcome of Assembly Projects \\
\hline A. Engages in appropriate pre-design activities & A. Interpret provided assembly documentation including \\
\hline B. Identifies and utilized correct part modeling commands & multi-view drawings, isometric drawings, assembly \\
\hline C. Creates acceptable part models of various robotic arm & drawings, etc. \\
\hline pieces & B. Creates acceptable part models of various pieces \\
\hline $\begin{array}{l}\text { D. Assembles and constrains arm pieces such that they may } \\
\text { operate in provided work envelope }\end{array}$ & $\begin{array}{l}\text { C. Assembles and constrains pieces so they interact and move } \\
\text { appropriately }\end{array}$ \\
\hline $\begin{array}{l}\text { E. Uses appropriate materials and fasteners in robotic arm } \\
\text { design }\end{array}$ & $\begin{array}{l}\text { D. Creates avi files showing and capturing part interaction } \\
\text { while moving }\end{array}$ \\
\hline F. Evaluates design and revises as needed & E. Evaluates design and revises as needed \\
\hline G. Creates acceptable part models of various gripper pieces & F. Develop appropriate documentation of design including \\
\hline $\begin{array}{l}\text { H. Assembles and constrains gripper pieces such that they } \\
\text { may operate in provided work envelope }\end{array}$ & assembly drawings. \\
\hline I. Uses appropriate materials and fasteners in gripper design & \\
\hline J. Assembles robotic arm/gripper and mount to base & \\
\hline K. Verify part interaction, clearances, and tolerances & \\
\hline L. Animates robotic arm and captures avi and screen images & \\
\hline $\begin{array}{l}\text { M. Develop appropriate documentation of design including } \\
\text { multiview, isometrics, \& sections, etc. }\end{array}$ & \\
\hline Outcomes for Typical Homework Problem & Outcome for Typical Quiz/Test \\
\hline $\begin{array}{l}\text { A. Identify and demonstrate mastery of a particular set of } \\
\text { commands to create solid model }\end{array}$ & $\begin{array}{l}\text { A. Within the allotted time, identify and demonstrate mastery } \\
\text { of a particular set of commands to create solid model }\end{array}$ \\
\hline $\begin{array}{l}\text { B. Create accurate model applying appropriate design } \\
\text { constraints }\end{array}$ & $\begin{array}{l}\text { B. Within the allotted time, create accurate model applying } \\
\text { appropriate design constraints }\end{array}$ \\
\hline C. Tolerance the part & C. Within the allotted time, tolerance the part \\
\hline D. Save the solid model and produce documentation on it & $\begin{array}{l}\text { C. Within the allotted time, save the solid model and produce } \\
\text { documentation on it }\end{array}$ \\
\hline
\end{tabular}

Figure 1. Example of students' project outcomes 
Table 1. Example of Kolb's learning style inventory

\begin{tabular}{|c|c|c|c|c|}
\hline \multirow[b]{2}{*}{ Statement } & \multicolumn{4}{|c|}{ Learning Modes } \\
\hline & $\mathrm{CE}$ : Concrete Experience & $\begin{array}{l}\text { RO: Reflective } \\
\text { Observation }\end{array}$ & $\begin{array}{c}\text { AC: Abstract } \\
\text { Conceptualization }\end{array}$ & $\begin{array}{c}\text { AE: Active } \\
\text { Experimentation }\end{array}$ \\
\hline When I learn... & $\begin{array}{l}\text { I like to deal with my } \\
\text { feelings. }\end{array}$ & $\begin{array}{l}\text { I like to watch and } \\
\text { listen. }\end{array}$ & I like to think about ideas. & I like to do things. \\
\hline $\begin{array}{l}\text { I learn best } \\
\text { when... }\end{array}$ & $\begin{array}{l}\text { I trust my hunches and } \\
\text { feelings. }\end{array}$ & $\begin{array}{l}\text { I listen and watch } \\
\text { carefully. }\end{array}$ & I relay on logical thinking. & $\begin{array}{l}\text { I work hard to get things } \\
\text { done. }\end{array}$ \\
\hline I learn by... & Feeling & Watching & Thinking & Doing \\
\hline $\begin{array}{l}\text { When I am } \\
\text { learning... }\end{array}$ & $\begin{array}{c}\text { I have strong feelings and } \\
\text { reactions. }\end{array}$ & $\begin{array}{l}\text { I am quiet and } \\
\text { reserved. }\end{array}$ & I tend to reason things out. & $\begin{array}{l}\text { I am responsible about } \\
\text { things. }\end{array}$ \\
\hline
\end{tabular}

\subsection{Data Collection and Analysis}

Data from the questionnaire was collected through an online media (i.e., Survey Monkey) as well as hardcopy printed surveys. The online method was instrumented twice during the first semester of the study and the hardcopy version was used during the second semester of the study. Surveys were given on the second day of the class. A change in survey information collection methods was implemented due to a desire from researchers to obtain higher participation rates. The hardcopy version increased participation rates effectively. The research assistant for the class passed the hardcopy survey out and collected them eliminating any potential influence the instructor's presence may have. Students were instructed to turn survey results in whether they choose to participate (filled them out) or not (left the survey blank). This method allowed the students to not feel peer pressure to fill out the survey as no other participant would know if the survey was actually completed. Survey data collected on the through Survey Monkey also prevented such inter-peer observation. IRB protocols were followed and permission was obtained prior to beginning the study.

To analyze data from the questionnaire, frequency scores were calculated for the learning modes. The two highest scores in the continuum of learning scores determine the learning style. For example, a student with scores $\mathrm{CE}$ (22), AE (19), AC (48), and RO (31) would be categorized into Assimilating because AC and RO were the two highest scores. Thus abstract conceptualization and reflective observation would represent this participant classified learning style. Cluster analysis was carried out to categorize students according to their answers on the learning style inventory.

\section{Results}

The results are organized into sections based on research questions guiding the current study. Demographic information is presented first, followed by descriptions of the two groups previous experiences.

\subsection{Demographic and Background Information on Participants' Learning Styles}

Descriptive statistics showed that the majority of students' ( 75 students) ages were 18-22, followed by $22-27$ (27 students), 27-32 (3 students), and 32-37 (3 students). One hundred and three students were male and only 5 students were female. The class was dominated by mechanical engineering freshmen and sophomore, 54 and 44 students, respectively. There were only 9 juniors and 1 senior. Moreover, 97 out of 108 students were White and the remaining students were identified as Native American, European American, Asian, Hispanic, and other ethnicity.

Background information about students' learning styles, both in synchronous online and face-to-face classes are described as follows. Findings revealed that most synchronous online students, 23 out of 30 students (77\%), were categorized into Converging. The rest of synchronous online students were categorized into assimilating ( 5 students) and accommodating (2 students) learning style. No student was categorized into diverging group for the synchronous online students.

Similar to synchronous online students, most face-to-face students, 46 out of 78 students $(59 \%)$, were categorized into Converging group. The assimilating group had 20 students while the accommodating and diverging groups had 11 students and 1 student, respectively (see Table 2 and Figure 2). 
Table 2. Learning styles distribution

\begin{tabular}{lccc}
\hline Class Type & $\begin{array}{c}\text { Accommodating } \\
(\mathrm{CE} / \mathrm{AE})\end{array}$ & $\begin{array}{c}\text { Diverging }(\mathrm{CE} / \mathrm{RO}) \\
\text { Assimilating } \\
(\mathrm{AC} / \mathrm{RO})\end{array}$ & $\begin{array}{c}\text { Converging }(\mathrm{AC} / \mathrm{AE}) \\
(16.67 \%)\end{array}$ \\
\hline Synchronous Online $(n=30)$ & $2(6.67 \%)$ & $0(0 \%)$ & $23(76.67 \%)$ \\
Face-to-Face $(n=78)$ & $11(14.10 \%)$ & $1(1.28 \%)$ & $25.64 \%)$ \\
\hline
\end{tabular}

Note. CE: Concrete Experience; RO: Reflective Observation; AC: Abstract Conceptualization; AE: Active Experimentation.
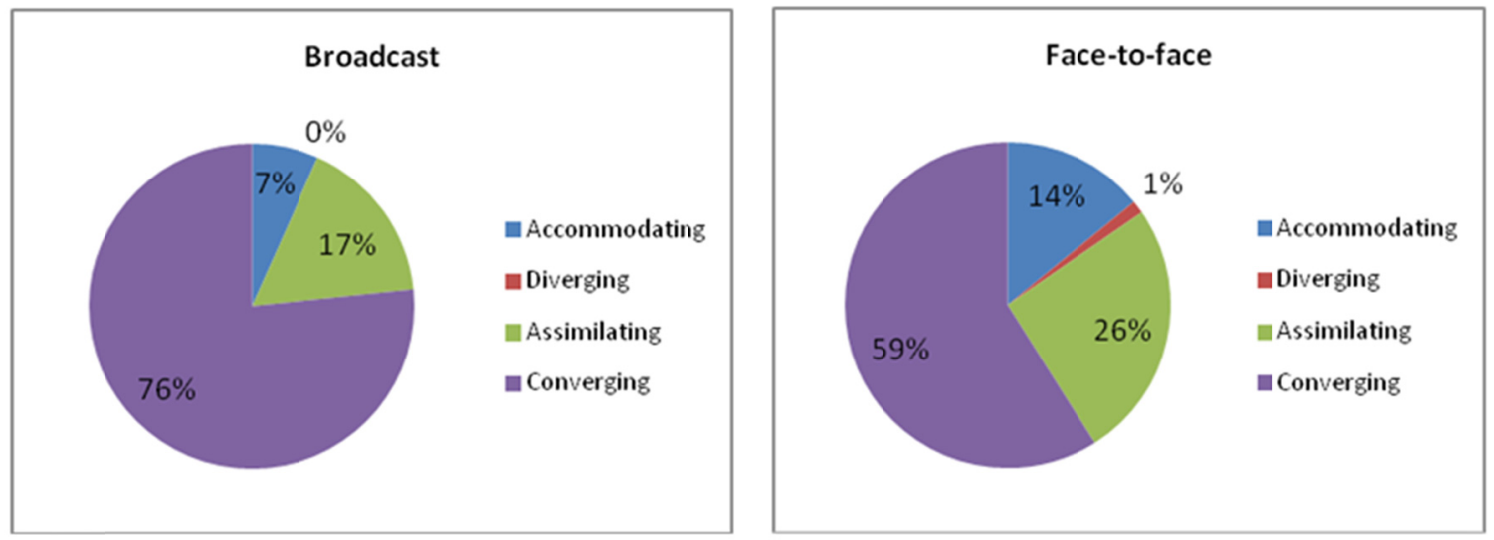

Figure 2. Percentage of students based on their learning styles

\subsection{Description of Synchronous Online Students' Previous Experiences}

Demographic findings revealed that $50 \%$ Accommodator students had industrial experience and $50 \%$ Accommodator students have experience using CAD software packages. Twenty percent of Assimilator students have industrial experience and all Assimilator students report having used CAD software packages. Moreover, $26 \%$ Converger students have industrial experience and all Converger students report having used CAD software packages (see Table 3).

\subsection{Description of Face-to-face Students' Previous Experiences}

Demographic findings also showed that $27 \%$ of the Accommodator students have industrial experience and that $36 \%$ of the Accommodator students have used CAD software packages. Fifteen percent of the Assimilator students have industrial experience and $80 \%$ of the Assimilator students report using CAD software packages. Last, 26\% Converger students have industrial experience and $85 \%$ Converger students report using CAD software packages (see Table 4).

Table 3. Description of synchronous online students' previous experiences

\begin{tabular}{lcc}
\hline Group & Industrial Experience & Usage of Software Package \\
\hline Accommodating $(\mathrm{n}=2)$ & $(n=1 ;$ Framer $)$ & $(n=1 ;$ Solid Edge [1]; Inventor [1]) \\
Diverging $(\mathrm{n}=0)$ & $\mathrm{n} / \mathrm{a}$ & $\mathrm{n} / \mathrm{a}$ \\
Assimilating $(\mathrm{n}=5)$ & $(n=1-$ Two years of Drafting Design and & $(n=5$; Solid Edge [3]; Inventor [2]; \\
& Theory in high school $)$ & AutoDesk's Mechanical Desktop [2]; Solid \\
& & Works [1]; AutoCAD 2000 [1] $)$ \\
Converging $(\mathrm{n}=23)$ & $(n=6-$ Machinist; Underground water and & $(n=23 ;$ Solid Edge [20]; Inventor [4]; \\
& drain plans 1 year experience; HVAC, Fire & AutoDesk's Mechanical Desktop [2]; Solid \\
& Suppression, Plumbing, Pipe-Fitter; Machinist, & Works [3]; Rino [1]; Pro Engineer [1]; \\
& Welder; Foreman on Framing crew $)$ & AutoDesk's AutoCAD Civil 3D 2009 [1]) \\
\hline
\end{tabular}

Note. Number in the bracket [x] represents number of students who had experience(s) using software package(s). 
Table 4. Description of face-to-face students' previous experiences

\begin{tabular}{|c|c|c|}
\hline Group & Industrial Experience & Usage of Software Package \\
\hline $\begin{array}{l}\text { Accommodating } \\
(n=11)\end{array}$ & $\begin{array}{c}(n=3 \text {; Internship at Zimmerman Engineering; Framer, Machinist; One } \\
\text { year machining school) }\end{array}$ & $(n=4 ;$ Solid Edge [4]; Inventor [2]) \\
\hline Diverging $(n=1)$ & ( $n=1 ;$ Metal/Woodworking at high school) & $\begin{array}{c}(n=1 ; \text { AutoDesk's Mechanical Desktop } \\
[1])\end{array}$ \\
\hline $\begin{array}{l}\text { Assimilating }(n= \\
20)\end{array}$ & $\begin{array}{c}(n=4 \text {; Machinist; Auto mechanic; Sheet metal fabrication; High school } \\
\text { woodshop) }\end{array}$ & $\begin{array}{c}\text { ( } n=16 \text {; Inventor [4]; A+ CAD [1]; Google } \\
\text { Sketchup [1]; Solid Edge [13]; Mastercam } \\
\text { [1]; AutoCAD [3]) }\end{array}$ \\
\hline $\begin{array}{l}\text { Converging }(n= \\
46)\end{array}$ & $\begin{array}{l}\text { ( } n=12 \text {; One year machinist assistant; Framer, cabinets; Wood shop; } \\
\text { Drafter \& technician; Cabinet \& Countertop maker; HVAC; School of } \\
\text { Bridgerland; Framing, foundations; Draftsman (12 years), framing ( } 12 \\
\text { years), machinist (2 years); Cabinet maker, CNC operator) }\end{array}$ & $\begin{array}{l}(n=39 ; \text { Solid Edge [34]; Solid Works [8]; } \\
\text { Inventor [9]; IDEAS [2]; AutoCAD [5]; NX } \\
\text { [2]; Catia [1]; AutoDesk's Mechanical } \\
\text { Desktop [2]; Cabinet Plus (for CNC) [1]) }\end{array}$ \\
\hline
\end{tabular}

\subsection{Description of Participants Mean Learning Style scores for Face-to-face and Synchronous Online Groups}

The findings show that the mean scores of learning styles is quite similar between the synchronous online and face-to-face groups (see Table 5).

\subsection{Answering the Research Question}

"Is there any difference on academic performance (final grades and open-ended problems) across learning styles between synchronous online and face-to-face classes?"

To answer the research question, the researchers conducted a series of Mann-Whitney tests to investigate whether significance difference exists across learning styles between synchronous online and face-to-face classes. Descriptive statistics of the data was developed to describe the results. Our findings show that the synchronous online group in general had higher final grades compared to the face-to-face group (see Table 6). Converger students in the synchronous online group showed a significantly higher score on their final grades than the Converger students in the face-to-face group $(Z=-2.324 ; \mathrm{p}<.05)$.

Findings also revealed that the synchronous online group had higher scores on the open-ended problem solving activity compared to face-to-face group across learning styles (see Table 7). Assimilator students in synchronous online group showed a significantly higher score on their final grade for the open ended activity than Assimilator students in face-to-face group $(\mathrm{Z}=-2.145 ; \mathrm{p}<.05)$. Converger students in the synchronous online group also showed a significantly higher score on their final grade for the open ended activity than the Converger students in the face-to-face group $(Z=-3.778 ; \mathrm{p}<.01)$.

Table 5. Mean scores of learning styles between synchronous online and face-to-face groups

\begin{tabular}{lcccc}
\hline Class group & Accommodating (CE/AE) & Diverging (CE/RO) & Assimilating (AC/RO) & $\begin{array}{c}\text { Converging } \\
(\mathrm{AC} / \mathrm{AE})\end{array}$ \\
\hline Synch. Online (SO) & $(n=2)$ & $(n=0)$ & $(n=5)$ & $(n=23)$ \\
Learning style & $35.50(2.83)$ & 0 & $36.80(1.35)$ & $36.15(2.30)$ \\
\hline Face-to-face (F2F) & $(n=11)$ & $(n=1)$ & $(n=20)$ & $(n=46)$ \\
Learning style & $37.95(3.25)$ & $35.50(\mathrm{n} / \mathrm{a})$ & $35.35(4.00)$ & $37.79(3.72)$ \\
\hline
\end{tabular}

Note. CE: Concrete Experience; RO: Reflective Observation; AC: Abstract Conceptualization; AE: Active Experimentation. 
Table 6. Mean scores of academic performance (final grade) across learning styles

\begin{tabular}{lcccc}
\hline Class group & Accommodating (CE/AE) & Diverging (CE/RO) & Assimilating (AC/RO) & $\begin{array}{c}\text { Converging } \\
(\mathrm{AC} / \mathrm{AE})\end{array}$ \\
\hline $\begin{array}{l}\text { Synch. Online (SO) } \\
\text { Final Grade }\end{array}$ & $(n=2)$ & $(n=0)$ & $(n=5)$ & $(n=23)$ \\
\hline Face-to-face (F2F) & $90.80(1.27)$ & 0 & $92.00(3.74)$ & $90.64(7.09)$ \\
Final Grade & $(n=11)$ & $(n=1)$ & $(n=20)$ & $(n=46)$ \\
\hline
\end{tabular}

Note. CE: Concrete Experience; RO: Reflective Observation; AC: Abstract Conceptualization; AE: Active Experimentation.

Table 7. Mean scores of academic performance (open-ended problems) across learning styles

\begin{tabular}{lcccc}
\hline Class & Accommodating (CE/AE) & Diverging (CE/RO) & Assimilating (AC/RO) & Converging (AC/AE) \\
\hline Synch. Online (SO) & $(\mathrm{n}=2)$ & $(\mathrm{n}=0)$ & $(\mathrm{n}=5)$ & $(\mathrm{n}=23)$ \\
Open-Ended Problem & $89.00(2.83)$ & 0 & $90.00(5.96)$ & $90.09(5.05)$ \\
\hline Face-to-Face (F2F) & $(\mathrm{n}=11)$ & $(\mathrm{n}=1)$ & $(\mathrm{n}=20)$ & $(\mathrm{n}=46)$ \\
Open-Ended Problem & $83.36(7.86)$ & $91.00(\mathrm{na})$ & $78.90(17.24)$ & $83.45(9.00)$ \\
\hline
\end{tabular}

Note. CE: concrete experience; RO: reflective observation; AC: abstract conceptualization; AE: active experimentation

\section{Conclusions and Discussion}

Our findings show that most students in the synchronous online engineering graphics course were categorized in Converging learning styles. This is also the case for the face-to-face group. These findings confirm for a mechanical engineering graphics course findings seen in a previous study conducted by Terrell and Dringus (2000) that involved information science students. The dominance of the Converger learning style is not unexpected given similar work studying engineering students (Felder \& Brent, 2005). In addition, these findings confirm Kolb's learning styles classification and work regarding the engineering profession (Kolb, 2009).

Although not statistically significant, synchronous online students' learning performance scores were greater than face-to-face students' scores for all categories of learners except Convergers. Of greater importance is the finding that the Converger synchronous online student learning performance scores were significantly greater than their face-to-face peers. Additional focus was given to the students' open-ended problem scores within the two different learning mediums. Results also indicate significantly better performance by synchronous online Assimilating and Converger students on their open-ended project scores. These results are encouraging when viewed with the potential to move engineering courses to a synchronous online course delivery method. As most engineering students classify as a Converging learning style, this study indicates that their learning style may positively impact their course performance. This study also shows that Assimilating students may respond well to open-ended problems delivered in a synchronous online educational environment.

A discussion on the potential reasons for Converger and Assimilator improved performance in a synchronous online course is warranted. It is important in doing so to remember that students in the studied face-to-face and synchronous online classes are similar in age and gender distribution. It is also noted that the classes were taught with the same curriculum and the same teacher. Students did not know ahead of time whether the course they signed up for would be synchronous online or face-to-face and could therefore not pre-select the method of instruction. The course delivered content through the same LMS system for both classes and the only intervention was focused on the instructor's presence. Lecture notes were identical between courses and the lectures themselves were as consistent as possible excluding individual student questions. The synchronous online course differed only in the synchronous delivered lecture presented by the instructor to the students. Access to the instructor was invited in both types of course via email.

It is possible that some aspect of student-teacher interaction that was not present in a synchronous online course may have impacts upon Converger and Assimilator students who engage in traditional face-to-face instruction. Such a mechanism could be related to the instructor's physical presence or the perceived organization of the course by students who take it in a synchronous online format. Face-to-face students may not perceive such organization as they can interact with the instructor readily for clarification. Converger's preference to work with "things" rather than people as well as Assimilators preferences to work with organized and accurate information may have predisposed them to better performance given the delivery mechanisms in the two types of classes. 
The inherent characteristics of Converger and Assimilator students in a synchronous online lecture model may naturally predispose the course for better performance by engineering students. For example, a Converger student who has been shown to respond well to computer assisted instruction (McNulty et al., 2009) may also respond well to a synchronous online instruction model due to a predisposition towards abstract conceptualization and active experimentation. They may rely more on their abstract conceptualization skills to understand material and their inclination towards active experimentation may be sated with their ability to interface with the software while their face-to-face peers may not hesitate to experiment as much with the software given the instructors physical presence in the room. Convergers may also find the synchronous online interface very appealing because it may be perceived as more authoritive and regimented as a consequence to its delivery online.

The abstract conceptualization characteristic present in Assimilators may also be appealed to with the open-ended problems found in the studied class. They thus may have more effectively engaged in this activity than their face-to-face peers. However, a question then arises as to why they did not significantly improve in their full course performance while Convergers did significantly. The answer may lie in their propensity for reflective observation. An open-ended problem may be more engaging to an Assimilator in a synchronous online environment because they may be forced to engage in more reflective observation than they would in a face-to-face course given perceptions of distance from the instructor. This reflective observation characteristic is probably not as dominantly manifested when students engage with the rest of the curriculum which yields itself to more direct solution processes. It is plausible that reflective observation is not as fundamental to performance on non-open-ended curriculum as active experimentation features. This reasoning explains why Convergers significantly performed better in the class as well as the open-ended problems while Assimilators only performed significantly better on the open-ended problems, and should be investigated more thoroughly in a targeted study.

Finally, with a realization that Convergers like to learn by trial and error in environments that allow them to fail (Felder \& Brent, 2005), it is quite possible that Convergers in the synchronous online course felt more secure in their attempts at solutions on all aspects of the course than their peers in the face-to-face classes. There may be a greater sense of security in the trial and error process when an instructor was not seen to "watch over their shoulders." While further study is encouraged the results in this study indicate that Convergers and Assimilators may take well to synchronous online engineering graphics courses.

\section{Implications and Further Works}

Our findings show that most students in the synchronous online engineering graphics course were categorized in Converging learning styles. This is also the case for the face-to-face group. These findings confirm a previous study conducted by Terrell and Dringus (2000) that involved information science students. The dominance of the Converger learning style is not unexpected given previous work studying engineering students (Felder \& Brent, 2005). In addition, these findings confirm Kolb's learning styles classification and work regarding the engineering profession (Kolb, 2009).

Further work is needed and will include the following. It is important to look at other learning style surveys beyond that developed by Kolb. With consideration towards the variety of engineering coursework that is being delivered online, future work should also look to incorporate courses such as Statics, Dynamics, Strengths, Electronics, etc. in a similarly designed research model. This research utilized a quasi-experimental design, and while very difficult, it would also be worthwhile to try to implement similar research using a fully experimental design where random assignment of students and instruments is instigated.

The work needs to be replicated to increase its statistical strength. The Diverging learning style was not represented in this studies synchronous online group and was severely underrepresented in the face-to-face group. In addition, the Accommodating group suffered underrepresentation and the Assimilating synchronous online group could have been greater in number. Low representation is expected from Diverging and Accommodating learning styles within engineering but it nevertheless would be interesting to collect more participants to replicate the findings. Additionally, it is suggested that this study continue into coursework that falls outside of engineering and thus encompasses the Diverging and Accommodating learning styles. Current understanding of many aspects or consequences to moving curriculum to a synchronous online medium are yet to be investigated and the case is also true outside of engineering courses. It is also felt that extending the population base beyond the demographic associated with this study would provide informative results involving a more diverse population base that may have differences in learning styles. Finally, to begin to develop an understanding to the mechanisms that cause the differences in the results, a qualitative component of data collection and analysis is encourage thus creating a mixed method approach that may mine student's attitudes and predispositions for 
analysis against the quantitative findings.

\section{Implications and Further Works}

The study is a quasi-experimental design that operated with a convenience sample of participants who signed up to take the courses. The students did not know the course would be synchronous online course until the first meeting time. While it is possible that the synchronous online students were simply better academic performers than their face-to-face peers it is likely improbable given the studies design. In addition, since the number of participants of each learning styles was based on the results of learning styles questionnaire analysis, the researchers could not control the similar number of participants in each learning style group. For example, there was no participant categorized in the Synchronous Online Diverging group. There was also a very limited number of participant categorized in the Face-to-Face Diverging group. The study targeted a mechanical engineering course and thus does not propose its results would be valid on other engineering majors. Work would be warranted to investigate other engineering majors in a similar designed study. Finally, as with most mechanical engineering studies, female representation was low. Continuation of the study in a longitudinal manner could possibly address an investigation into aspects of learning style, academic performance, and instructional design that may be influenced by gender.

\section{Acknowledgments}

Thanks are expressed to Adam Norris for his help in collecting the data used in the study while fulfilling his role as an undergraduate research assistant at the time.

\section{References}

Abidin, M. J. Z., Rezaee, A. A., Abdullah, H. N., \& Singh, K. K. B. (2011). Learning Styles and Overall Academic Achievement in a Specific Educational System. International Journal of Humanities and Social Science, 1(10), 143-152.

Allen, E. I., \& Seaman, J. (2005). Online nation: Five years of growth in online learning. Needham, MA: The Sloan Consortium. http://dx.doi.org/10.1111/j.1354-5078.2005.214_14.x

Allen, E. I., \& Seaman, J. (2008). Staying the course: Online education in the United States. Needham, MA: The Sloan Consortium.

Allen, E. I., \& Seaman, J. (2010). Class differences: Online education in the United States. Needham, MA: The Sloan Consortium.

Allen, E. I., \& Seaman, J. (2011). Going the distance: Online education in the United States. Needham, MA: The Sloan Consortium.

Anderson, J. A., \& Adams, M. (1992). Acknowledging the learning styles of diverse student populations: Implications for instructional design. In L. L. Border, \& N. Van Note Chism (Eds.), New Directions for Teaching and Learning (pp. 19-33). San Francisco: Jossey-Bass Publishers, Inc. http://dx.doi.org/10.1002/tt.37219924904

Bargar, J. R., Bargar, R. R., \& Cano J. (1994). Discovering learning preferences and learning differences in the classroom. Columbus: The Ohio Agricultural Education Curriculum Materials Service, The Ohio State University.

Bourne, J., Harris, D., \& Mayadas, F. (2005). Online Engineering Education: Learning Anywhere, Anytime. Journal of Engineering Education, 94(1), 131-146. http://dx.doi.org/10.1002/j.2168-9830.2005.tb00834.x

Cano, J. (1999). The Relationship Between Learning Style, Academic Major, and Academic Performance of

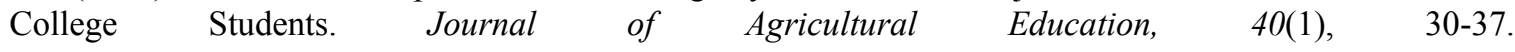
http://dx.doi.org/10.5032/jae.1999.01030

Cano, J., \& Garton, B. L. (1994). The Relationship Between Agriculture Preservice Teachers' Learning Styles and Performance in a Methods Of Teaching Agriculture Course. Journal of Agricultural Education, 35(2), 6-10. http://dx.doi.org/10.5032/jae.1994.02006

Cano-Garcia, F., \& Hughes, E. H. (2000). Learning and Thinking Styles: An Analysis of their Interrelationship and Influence on Academic Achievement. Educational Psychology, 20(4) 413-430. http://dx.doi.org/10.1080/713663755

Chen, X., Olmi, C., \& Song, G. (2010, June). A remote bridge experiment with vibration control. Proceedings of International Symposium on Life-Cycle Performance of Bridges and Structures (pp. 844-849). Changsha, China. 
Chen, X., Song, G., \& Zhang, Y. (2010). Virtual and remote laboratory development: A review. Proceedings of Earth and Space 2010: Engineering, Science, Construction, and Operations in Challenging Environments (pp. 3843-3852), Honolulu, HI.

Cooper, M. (2005). Remote Laboratories in Teaching and Learning-Issues Impinging on Widespread Adoption in Science and Engineering Education. International Journal of Online Engineering (iJOE), 1(1), 1-7. Retrieved from http://oro.open.ac.uk/9748/1/iJOE-2005-11.pdf

Creswell, J. W. (2009). Research design: Qualitative, quantitative, and mixed methods approaches. Los Angeles: Sage.

Dahbi, A., Elkamoun, N., \& Berraissoul, A. (2006, October). Adaptation and optimisation of pedagogical paths by Ant's algorithm. Paper presented at the ICTTA, $2^{\text {nd }}$ Information and Communication Technologies (pp. 546-551), Damascus.

DeTure, M. (2004). Cognitive style and self efficacy: Predicting Student Success in Online Distance Education. The American Journal of Distance Education, 18(1), 21-38. http://dx.doi.org/10.1207/s15389286ajde1801_3

Diaz, D. P., \& Cartnal, R. B. (1999). Students' Learning Styles in Two Cases: Online Distance Learning and Equivalent On-Campus. College Teaching, 47(4) 130-135. http://dx.doi.org/10.1080/87567559909595802

Dunn, R. S., \& Dunn, K. J. (1979). Learning Styles/Teaching Styles: Should They...Can They...Be Matched? Educational Leadership, 36, 238-244.

Dupin-Bryant, P. (2004). Pre-Entry Variables Related to Retention in Online Distance Education. American Journal of Distance Education, 18(1), 199-206. http://dx.doi.org/10.1207/s15389286ajde1804_2

Eom, S. B., Wen, H. J., \& Ashill, N. (2006). The Determinants of Student's Perceived Learning Outcomes and Satisfaction in University Online Education: An Empirical Investigation. Decision Sciences Journal of Innovative Education, 4(2), 215-235. http://dx.doi.org/10.1111/j.1540-4609.2006.00114.x

Felder, R. M., \& Brent, R. (2005). Understanding Student Differences. Journal of engineering education, 94(1), 57-72. http://dx.doi.org/10.1002/j.2168-9830.2005.tb00829.x

Felder, R. M., \& Silverman, L. K. (1988). Learning and Teaching Styles in Engineering Education. Journal of Engineering Education, 78(7), 674-681.

Felder, R. M., \& Spurlin, J. E. (2005). Applications, Reliability, and Validity of the Index of Learning Styles. International Journal of Engineering Education, 21(1), 103-112.

Garland, D., \& Martin, B. (2005). Do Gender and Learning Style Play a Role in How Online Courses Should be Designed. Journal of Interactive Online Learning, 4(2), 67-81.

Garton, B. L, Spain, J. N., Lamberson, W. R., \& Spiers, D. E. (1999) Learning Styles, Teaching Performance, and Student Achievement: A Relational Study. Journal of Agricultural Education, 40(3), 11-20. http://dx.doi.org/10.5032/jae.1999.03011

Gee, D. B. (1990). The impact of Students' preferred learning style variables in a distance education course: A case study. Portales: Eastern New Mexico University. ERIC Document Reproduction Service No. ED 358 836.

Grose, T. K. (2003). Can distance education be unlocked? Prism, 12(8), 19-23.

Hesselink, L., Rizal, D., Bjornson, E., Paik, S., Batra, R., Catrysse, P. B., . . . Wong, A. (2003). Stanford CyberLab: Internet Assisted Laboratories. International Journal of Distance Education Technologies, 1(1), 21-39. http://dx.doi.org/10.4018/jdet.2003010102

Hsieh, P. H., \& Dwyer, F. (2009). The Instructional Effect of Online Reading Strategies and Learning Styles on Student Academic Achievement. Educational Technology and Society, 12(2), 36-50.

Huett, J. B., Kalinowski, K. E., Moller, L., \& Huett, K. C. (2008). Improving the Motivation and Retention of Online Students Through the Use of ARCS-Based e-mails. The American Journal of Distance Education, 22(3), 159-176. http://dx.doi.org/10.1080/08923640802224451

Ibrahim, W., \& Morsi, R. (2005). Online engineering education: A comprehensive review. Proceedings of the 2005 American Society for Engineering Education Annual Conference \& Exposition, ASEE, Portland, OR.

Junko. (1998). Learning styles and error correction: How do learning styles affect students' perceptions towards error correction in a foreign language classroom? 
Kayes, D. C (2005). Internal Validity and Reliability of Kolb's Learning Style Inventory Version 3 (1999). Journal of Business and Psychology, 20(2), 249-257. http://dx.doi.org/10.1007/s10869-005-8262-4

Koehler, M. J., Mishra, P. A., Herhey, K., \& Peruski, A. (2004). With a Little Help from Your Students: A New Model for Faculty Development and Online Course Design. Journal of Technology and Teacher Education, 12(1), 25-55.

Kolb, A. Y. (2005). The Kolb learning style inventory-version 3.12005 technical specifications. Boston, MA: Hay Resource Direct, 200.

Kolb, A. Y., \& Kolb, D. A. (2005a). The Kolb learning style inventory-version 3.12005 technical specifications. Boston, MA, Hay Resources Direct.

Kolb, A. Y., \& Kolb, D. A. (2005b). Learning Styles and Learning Spaces: Enhancing Experiential Learning in Higher Education. Academy of Management Learning and Education, 4(2), 193-212. http://dx.doi.org/10.5465/AMLE.2005.17268566

Kolb, D. A. (1984). Experential learning. Prentice-Hall Inc. Englewood Cliffs, New Jersey.

Kolb, D. A. (1985). Learning style inventory (Revised Edition). Boston, MA: Hay Group, Hay Resources Direct.

Leite W. L., Svinicki, M., \& Shi, Y. (2010). Attempted Validation of the Scores of the VARK: Learning Styles Inventory with Multitrait-Multimethod Confirmatory Factor Analysis Models. Educational and Psychological Measurement, 70(2), 323-339. http://dx.doi.org/10.1177/0013164409344507

Litzinger, T. A., Lee, S. H., Wise, J. C., \& Felder, R. M. (2007). A Psychometric Study of the Index of Learning $\begin{array}{lllll}\text { Styles. Journal of } & \text { Engineering }\end{array}$ http://dx.doi.org/10.1002/j.2168-9830.2007.tb00941.x

Lynch, T. G., Woelfl, N. N., Steele, D. J., \& Hanssen, C. S. (1998). Learning Style Influences Student Examination Performance. The American Journal of Surgery, 176, 62-66. http://dx.doi.org/10.1016/S0002-9610(98)00107-X

McNulty, J. A., Sonntag, B., \& Sinacore, J. M. (2009). Evaluation of Computer-Aided Instruction in a Gross Anatomy Course: A Six-Year Study. Anatomical Sciences Education, 2(1), 2-8. http://dx.doi.org/10.1002/ase.66

Minichiello, A., Goodridge, W. H., Blake, T. D., \& Sam, D. D. (2011, June). Team teaching that goes the distance: Team instruction for a broadcast introductory engineering course. Paper presented at the $118^{\text {th }}$ ASEE Annual Conference and Exposition. Vancouver, BC, Canada.

Myers, I. B. (1990). Introduction to type: A description of the theorv and application of the Myers-Briggs Type Indicator. Palo Alto, CA: Consulting Psychologists Press, Inc.

Myers, I. B. (1995). Gifts differing: Understanding personality type. Davies-Black Publishing.

Myers, I. B., McCaulley, M. H., Quenk, N., \& Hammer, A. (1998). MBTI handbook: A guide to the development and use of the Myers-Briggs Type Indicator (3rd ed.). Consulting Psychologists Press.

Peterson, G. D., \& Feisel, L. D. (2002, August). e-Learning: The challenge for engineering education. Proceedings, e-Technologies in Engineering Education, A United Engineering Foundation Conference (pp. 164-169), Davos, Switzerland. Retrieved from http://services.bepress.com/eci/etechnologies/

Picciano, A. G. (2002). Beyond Student Perceptions: Issues of Interaction, Presence, and Performance in an Online Course. Journal of Asynchronous Learning Networks, 6(1), 21-40.

Saad, M., Saliah-Hassane, H., Hassan, H., El-Guetioui, Z., \& Cheriet, M. (2002). "A synchronous remote accessing control laboratory on the Internet," in Engineering Education and Research-2001: A Chronicle of Worldwide Innovations, W. Aung, Ed. et al. Arlington, NY: iNEER/Begell House Publishers, 2002 iNEER Special Volume.

Schroeder, C. C. (1993). New students - new learning styles. Change: The Magazine of Higher Learning, 25(5), $21-26$.

Simpson, O. (2006). Predicting Student Success in Open and Distance Learning. Open Learning: The Journal of Open and Distance Learning, 21(2), 125-138. http://dx.doi.org/10.1080/02680510600713110

Subic, A., \& Maconachie, D. (2004). Flexible Learning Technologies and Distance Education: A Teaching and Learning Perspective. European Journal of Engineering Education, 29(1), 27-40. http://dx.doi.org/10.1080/0304379032000129322 
Swan, K. (2001). Virtual Interaction: Design Factors Affecting Student Satisfaction and Perceived Learning in Asynchronous Online Courses. Distance Education, 22(2) 306-331. http://dx.doi.org/10.1080/0158791010220208

Swan, K. (2003). Learning effectiveness: What the research tells us. In J. Bourne, \& J. C. Moore (Eds.), Elements of quality online education: Practice and direction (pp. 13-45). Needham, MA: Sloan Center for Online Education.

Terrell, S. R., \& Dringus, L. (2000). An Investigation of the Effect of Learning Style on Student Success in an Online Learning Environment. Journal of Educational Technology Systems, 28(3), 231-238. http://dx.doi.org/10.2190/R53M-BVBD-UGV5-77EH

Torres, R. M. (1993). The cognitive ability and learning style of students enrolled in the college of agriculture at the Ohio State University (Unpublished doctoral dissertation). The Ohio State University, Columbus.

Torres, R. M., \& Cano, J. (1993). Learning Styles of Students in a College of Agriculture. Journal of Agricultural Education, 35(4), 61-66.

Warn, T. S. (2009). Students' learning styles and their academic achievement for taxation course - A comparison study. Proceedings of the $2^{\text {nd }}$ International Conference of Teaching and Learning (pp. 1-7), INTI University College, Malaysia.

Weirstra, R. F. A., \& DeJong, J. A. (2002). A scaling theoretical evaluation of Kolb's learning style inventory-2. In M. Valcke \& D. Gombeir (Eds.), Learning styles: reliability and validity (pp. 431-440). Proceedings of the seventh annual European learning styles information network, 26-28 June. Ghent, Belgium: University of Ghent.

Yeung, A., Read, J., \& Schimd, S. (2005). Students' learning styles and academic performance in first year chemistry. In D. Merrett (Ed.), Proceedings of the Blended Learning in Science Teaching and Learning Symposium (pp. 137-142). Sydney, NSW: UniServe Science.

\section{Copyrights}

Copyright for this article is retained by the author(s), with first publication rights granted to the journal.

This is an open-access article distributed under the terms and conditions of the Creative Commons Attribution license (http://creativecommons.org/licenses/by/4.0/). 